\title{
The Development of Small Enterprises During and After Crisis: Comparative Analysis of Greece and Poland
}

\author{
Simeon Karafolas ${ }^{\uparrow 1}$ and Maciej Woźniak² \\ 'Department of Accounting and Finance, University of Western Macedonia, Greece \\ Department of Economics, Finance and Environmental Management, AGH University of Science and Technology, Poland
}

\begin{tabular}{l}
\hline ARTICLE INFO \\
\hline Article History \\
Received 20 August 2020; \\
Accepted 07 September \\
2020 \\
\hline JEL Classifications \\
L16, L22, G01
\end{tabular}

L16, L22, G01

Keywords:

Small enterprises, Economic crisis, Greece, Poland \begin{abstract}
Purpose:

The purpose of the paper is to offer a comparative analysis of the development of small enterprises in Greece and Poland in the period just after global financial crisis which turned into an economic and social crisis for some countries, as the Greek example. The paper aims to discuss differences and similarities of small enterprises in two countries that suffered to a different level of the economic crisis.

Design/methodology/approach:

The authors decided to adopt three quantitative measures determining the degree of development of these companies: the number of active enterprises, the number of employees and the contribution to the Gross Domestic Product (GDP). The above measures were analyzed against the background of changes in the economic growth rate.

Findings:

Both countries were affected by the economic crisis but to a different level. Especially Greek economy suffered from the consequences of the austerity policy applied as a consequence of the agreement to obtain the international financial support. Poland on the contrary did not have to apply such an austerity program. Crisis consequences had severe consequences on the economy and negative effects on the GDP of these countries.

Research limitations/implications:

It should be noted that the presented results are based on quantitative methods, while the economic development also covers qualitative issues. Nevertheless, the analysis of data suggests the existence of a relationship between the adopted measures of small enterprises development and the value of GDP. Therefore, it indicates the need for further research, using more advanced methods of analysis. It is also worth expanding the research using qualitative methods.

Originality/value:

The paper contributes to the market failure theory in the area of macroeconomic business cycles. As the downswings because of crises influence on activity of enterprises, there is a need of appropriate government intervention. The analyzed examples suggest that higher level of monetary and credit policy in Poland seems to have a positive impact on the development of small enterprises in the analyzed space time. On the contrary, the austerity program in Greece might negatively affect the small companies.
\end{abstract}

\section{Introduction}

Small and medium enterprises have a crucial role in the economy and the social cohesion. Their role is particularly important in periods of economic and even social crisis. Quite relevant are the examples for the countries that suffered of economic and social crisis. Greece is one of these examples for the decade of 2010. The purpose of the paper is to offer a comparative analysis of the development of small enterprises in Greece and Poland in the period just after global financial crisis which turned into an economic and social crisis for some countries, as the Greek example. The examination focused on the evolution of three parameters: the number small enterprises, the number of employees in small enterprises and the contribution of these enterprises to the country's gross domestic product, (GDP). The paper aims to discuss differences and

+ Corresponding author: Simeon Karafolas

Email: skarafolas@uowm.gr 
similarities of small enterprises in two countries that suffered to a different level of the economic crisis. Further, one of them, Greece, participating to the Eurozone reduces its possibilities of monetary and credit policy; it not the case for Poland that has a higher degree of monetary and credit policy execution. In the Greek case, the austerity program limited further the possibilities of economy and social policy. Greece had to follow an austerity program due to the obligations of the financial assistance the country received on 2010 and later by International Monetary Fund, European Central Bank and European Commission. Consequences were very serious on the economic, social and financial level; see for example Karafolas, (2018), Karafolas and Kleanthous, (2019).

The economic consequences of the global financial crisis were much more serious in the case of Greece compared to Poland. In Greece a major economic downturn appears with the decline of the GDP, the public consumption and the investments although the public financial help through several programs as the LEADER initiative, (see Karafolas, (2013), for LEADER initiative); on the contrary the very important rising of the unemployment and the non-performing loans (NPLs) is observed, table 1. In the case of Poland a continuous growth of GDP and public consumption is observed while average unemployment rate remains, in average, almost the half compared to Greece and the NPLs remain very limited compared to Greek case the time period 2011-2017, table 1 .

Table 1. Evolution of macroeconomic indicators in Greece and Poland, (rate and annual change, \%)

\begin{tabular}{lccccccccc}
\hline Greece & $\mathbf{2 0 0 9}$ & $\mathbf{2 0 1 0}$ & $\mathbf{2 0 1 1}$ & $\mathbf{2 0 1 2}$ & $\mathbf{2 0 1 3}$ & $\mathbf{2 0 1 4}$ & $\mathbf{2 0 1 5}$ & $\mathbf{2 0 1 6}$ & $\mathbf{2 0 1 7}$ \\
\hline Gross Domestic Product & $-2,3$ & $-4,2$ & $-9,2$ & $-7,3$ & $-3,2$ & 0,7 & $-0,4$ & $-0,2$ & 1,5 \\
Public consumption & 7,6 & $-9,0$ & $-7,0$ & $-7,2$ & $-5,5$ & $-1,2$ & 1,6 & $-0,7$ & $-0,4$ \\
Investments & $-11,4$ & $-17,4$ & $-20,7$ & $-23,4$ & $-8,3$ & $-4,4$ & 0,7 & 4,7 & 9,1 \\
Unemployment of the year & 9,6 & 12,7 & 17,9 & 24,4 & 27,5 & 26,5 & 24,9 & 23,5 & 21,5 \\
Non-performing to total loans $(*)$ & 9,5 & 14,1 & 21,5 & 31,3 & 31,2 & 43,5 & 48,1 & 48,5 & 47,2 \\
\hline Poland & $\mathbf{2 0 0 9}$ & $\mathbf{2 0 1 0}$ & $\mathbf{2 0 1 1}$ & $\mathbf{2 0 1 2}$ & $\mathbf{2 0 1 3}$ & $\mathbf{2 0 1 4}$ & $\mathbf{2 0 1 5}$ & $\mathbf{2 0 1 6}$ & $\mathbf{2 0 1 7}$ \\
\hline Gross Domestic Product & 2,8 & 3,6 & 5,0 & 1,6 & 1,4 & 3,3 & 3,8 & 3,7 & 4,9 \\
Public consumption & 3,5 & 2,6 & 3,3 & 0,8 & 0,3 & 2,6 & 3,0 & 3,9 & 4,5 \\
Investments & $-12,6$ & 9,4 & 1,8 & $-3,9$ & $-1,9$ & 12,8 & 4,9 & $-2,0$ & 7,9 \\
Unemployment of the year & 10,4 & 12,9 & 13,1 & 13,2 & 14,2 & 13,9 & 11,9 & 10,2 & 8,5 \\
Non-performing to total loans & 7,2 & 7,8 & 9,0 & 8,3 & 8,9 & 8,6 & 8,2 & 7,6 & 6,9 \\
\hline
\end{tabular}

(*) Including all commercial and cooperative banks

Source: Bank of Greece, 2016, Bank of Greece, 2019 and Bank of Greece, 2019a; Polish Agency for Enterprise Development and Central Statistical Office of Poland

The importance of small companies is crucial in the economy of both countries. Small companies form 0-49 employees are more than 99,5\% of all companies in Greece, (Eurostat, 2019), and in Poland they are 99\% of all economic entities (Raport o stanie sektora małych i średnich przedsiębiorstw w Polsce, 2018, pp. 10-11). In Greece small companies employed almost 70\% of all employees during the decade 2008-2017, (Eurostat, 2019). In Poland they employ about $52 \%$ of employees and produce almost 38,5\% of GDP (Raport o stanie sektora małych i średnich przedsiębiorstw w Polsce, 2018, p 11). During the examined period significant changes have occurred for the Greek example. Macroeconomic parameters such as the decline of GDP, the decline of public and private consumption, the growth of unemployment and in particular non-performing loans had significant influence on these companies. They have occurred earlier in the Polish case with accession of Poland to the European Union (EU) in 2004 concerning among others inflow of funds for state aid, competition on the single European market as well as legal changes. Moreover, the external factors influenced significantly on the development of small enterprises, mainly at the beginning of the decade for both countries. The paper is organized as follows. First, a literature review was conducted followed by research questions and methodology. Next, the development of small companies was analyzed, based on empirical data. Finally, conclusions and directions of further research are indicated.

\section{Literature review, research questions and methodology}

Research on the development of the SMEs is very common and results are disseminated in academic literature. That indicates the importance of this topic for economics. The European Commission publishes reports on SMEs. Reports show the recovery of SMEs for most of countries after the global crisis that appears on the employment as well, see 
Muller et al. 2015, 2016 and 2017. Criscuolo et al, 2014 on a study on 18 countries, mainly from OECD, concluded that that among SMEs, mostly young firms are job creators contrary to old SMEs who tend to destroy jobs. Annual report on European SMEs 2018/2019 concluded on the strong contribution of SMEs to the value added; more interesting is that the contribution is stronger the last years 2016-2018 compared to the longer period 2013-2018 and it is entirely due to micro SMEs, (Muller et al. 2019)

In Poland, the development began with the start of economic transformation and the appearance of small, private companies. Among many scientific centers that have taken up this subject, we should mention in particular Łódź, (see Piasecki, 1998, 2002; Matejun, 2015), Gdańsk, (see Daszkiewicz, 2005, 2007; Wasilczuk, 2005; Dominiak, 2005 and 2010) or Krakow, (see Bednarczyk, 2004; Borowiecki and Siuta-Tokarska, 2009; Wach, 2008). As a part of the latter, it is also worth paying attention to AGH University of Science and Technology, Faculty of Management, (including Peszko and Duda, 2004; Woźniak, 2012; Duda and Woźniak, 2018).

In the Greek case, the Union of Hellenic Chambers of Commerce (UHCC) and the General Confederation of Professionals and the Craftsmen of Greek Merchants presented works on SMEs as representative organizations of SMEs. On 2014 a policy document formulating policy proposals for SMEs in Greece was prepared by UHCC, (UHCC and the Task Force for Greece, 2014).

However, it should be noted that the conducted researches often included SMEs sector as a whole. However, it is worth mentioned the differences between small enterprises and medium-sized companies. Despite, the former was not usually the main topic of research or only in short time span. This indicates the existence of research gap. Meanwhile, the importance of small businesses for the Greek and Polish economy respectively, as mentioned earlier, is of great importance.

The adoption of three quantitative measures determining the degree of development of these companies was decided: the number of active enterprises, the number of employees and the contribution to the GDP. The above measures were analyzed against the background of changes in the economic growth rate. The period studied is therefore somewhat limited by data availability and covers the years $2010-2017$.

It should be noted that for a relatively long time microenterprises were included into the sector of small companies. Therefore, it is not possible to separate their data for the adopted research period, especially in the case of the number of employees and the contribution to GDP. Given the number of active companies, the threshold of the basic criterion for separation of micro companies, which is the size of employment, has changed. In connection with the above, it was assumed in the article that the term: small enterprises also include microenterprises. Three research questions were set up:

a/ How the number of active small enterprises was changing?

b/ How the number of people employed in small enterprises was changing?

c/ How the contribution of small enterprises to GDP was changing?

The desk research method and data analysis was chosen. The research results can contribute to the area of economics and be of interest to entrepreneurs themselves. This can also be useful for decision-makers in the process of planning economic policy, including the allocation of EU funds to support small businesses.

\section{Data analysis}

\subsection{Definition of small enterprise}

Determining the exact term of small company has been necessary. In the EU countries, the official definition has been adopted on the recommendation of the European Commission issued in the year 2003 and supplemented in 2005 . A small company must meet the following criteria: a/ staff headcount, b/ annual turnover or annual balance sheet total, (European Commission, 2016).

For the first criterion, a small enterprise can employ 10 to 49 persons. Due to the possibility of, among others hiring or dismissing/leaving employees as well as various working hours, the so-called Annual Work Units (AWU) was adopted. This measure covers those persons who worked full-time the entire reference year. For seasonal workers, part-time employees or those who have not worked all year, a fraction of the AWU is calculated, (Nowa definicja MŚP, 2006; Woźniak, 2012).

Second criterion, the financial situation, can take two forms: turnover or balance sheet. One of them must be below the equivalent of 10 million euros. Both indicators relate to the last accounting year, (Nowa definicja MŚP, 2006; Woźniak, 2012).

There is also additional criterion - independence, which was not used in earlier official definitions. In this case, three types of business entities were distinguished: autonomous, partner, linked. They are separated based on their share in the capital of a company or voting rights. In the case of a partner company, this means that the data must be proportionally added to the above mentioned criteria: employment and financial situation. For a related enterprise, $100 \%$ of the value of these measures should be added. There are, however, exceptions to the above rules. These include venture capital funds (Nowa definicja MŚP, 2006; Woźniak, 2012).

\subsection{The Polish case}

The statistics comes from two main sources. The first one is the Polish Agency of Enterprise Development (PARP), which provides data about the number of: active small companies, employed in small enterprises and their contribution to GDP. The second source is the Central Statistical Office (GUS) of Poland considering the value of real GDP in Poland. 
After the accession to the European Union the number of active small companies began to rise, amounted nearly 1,9 million entities. At that time, the growth rate of Polish GDP also accelerated. However, the global economic crisis negatively affected the GDP, which coincided with a decrease in the number of small enterprises in 2009 to about 1,7 million. Nevertheless, from 2010 their number began to grow again, although at a slow pace, reaching at the end of the analyzed period almost 2 million entities, figure 1 .

Figure 1. The number of active small enterprises and real GDP in Poland in the years $2010-2017$

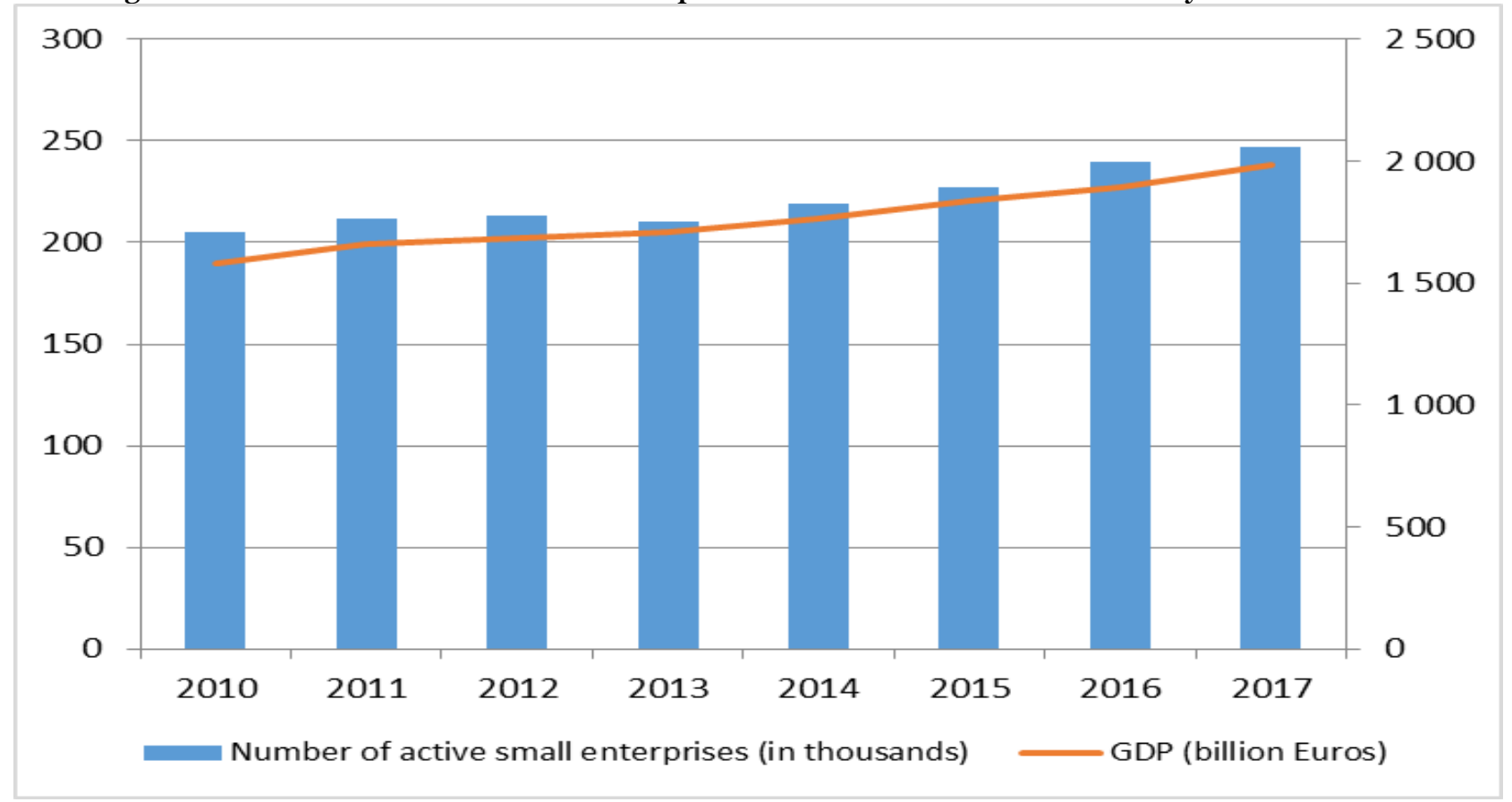

Source: Own study based on Reports on the data from PARP and GUS.

Taking the number of employees into consideration, the maximum point, almost 5 million, was reached in 2008 , after the accession to the EU. However, in 2009 there was a slight decline, coinciding with the global economic crisis. Since then, the number of employees in small businesses changed a little, oscillating around 4,8 million employees, figure 2. The maximum point was reached in 2017. It should be noted that in those years there was quite stable GDP growth.

Figure 2. The number of employed in small enterprises and real GDP in Poland the years $2010-2017$

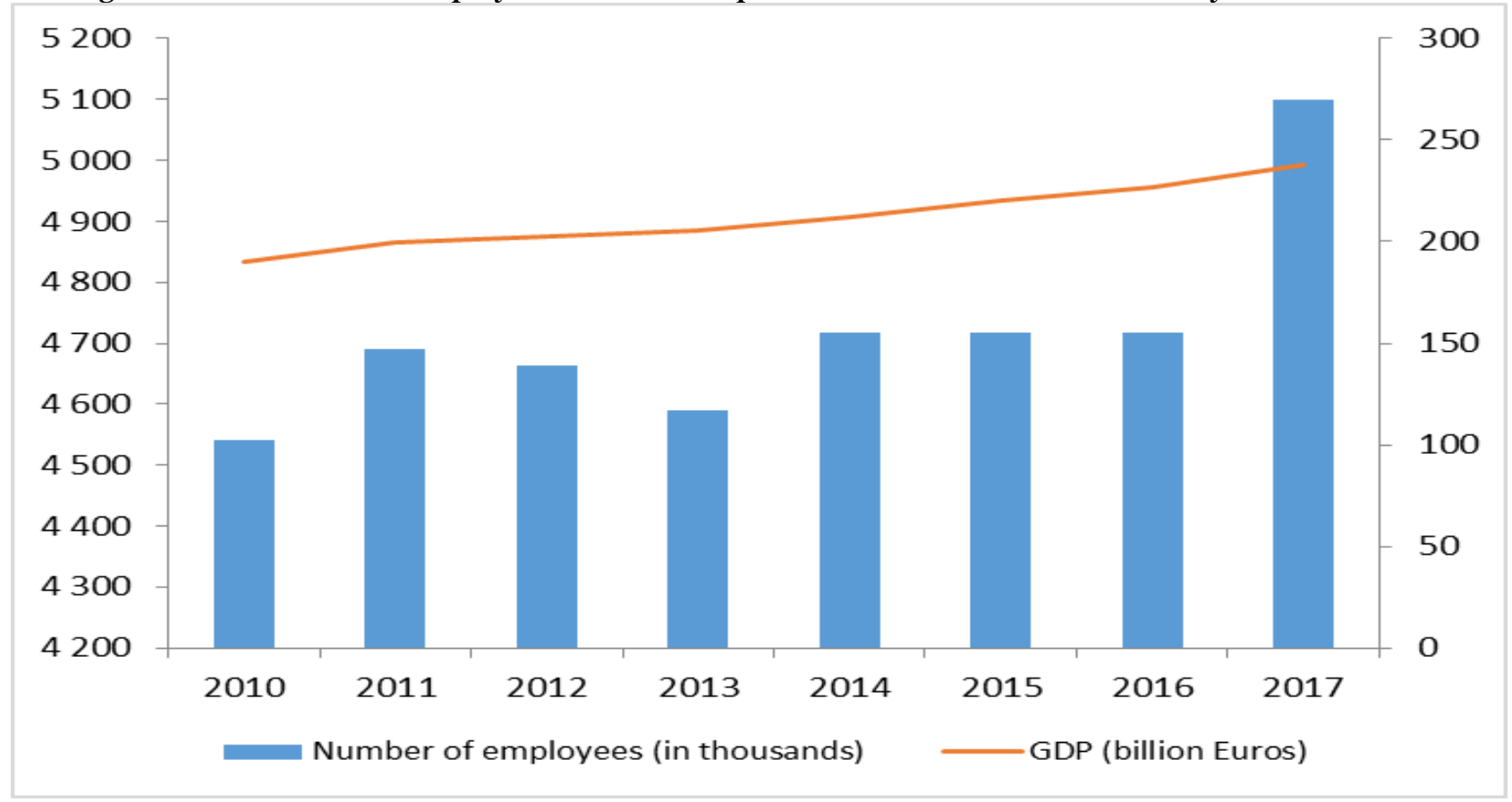

DOI: $10.25103 /$ ijbesar.132.03 
The contribution of small enterprises to GDP at the beginning of the decade stabilized. The minimum point was reached in 2011, a little more than 37\%. There was the slight rise in 2012, but then the indicator increased sharply in subsequent years, figure 3. It should be noted, however, that in this period there was a significant increase of Polish GDP. It means, therefore, that the value of GDP generated by small companies increased, although their percentage share was rather stable.

Figure 3. Contribution of small enterprises to GDP and real GDP in Poland in the years $2010-2017$

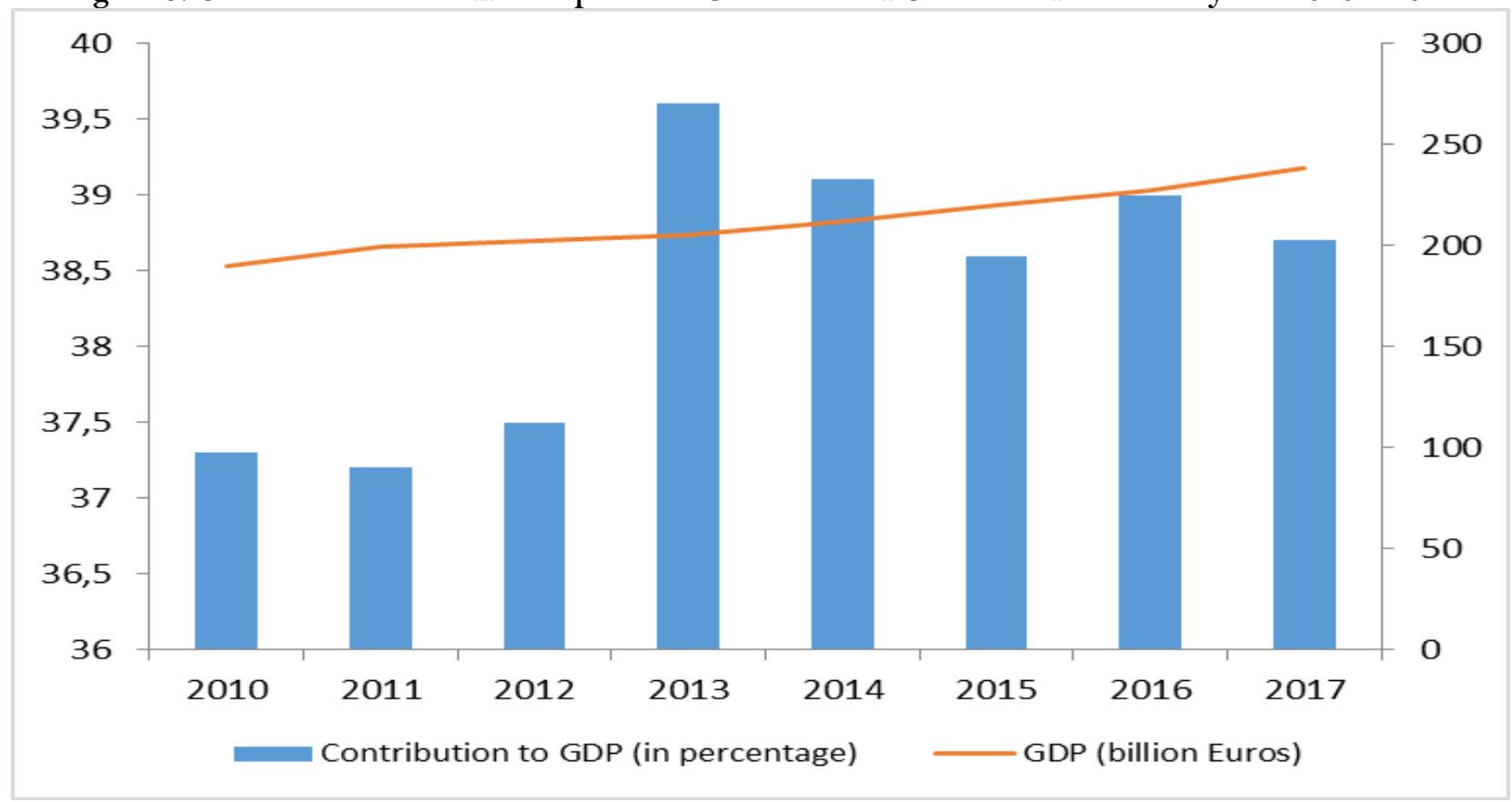

Source: As figure 1

\subsection{The greek case}

In the greek case, statistics had numerous problems regarding enterprises. One of them has been the growth of the number of companies in the sectors of agriculture, forestry and fishing for tax reasons (Decision on the Exemption from the obligation to keep books and issuance of data by the farmers of the specialist and established, Journal of Government, 3367B'/31/12/2013). Data used is provided from Eurostat Data Explorer, (Eurostat 2019). Data used is for the follow sectors: accommodation and food services, construction, information and communication, manufacturing, mining and quarrying, professional, real estate activities, repair motor vehicle and motorcycles, scientific and technical activities, transportation and storage, whole sale retail trade.

Consequences of the crisis and the adjustment program appear at the beginning of the period with the decline of the GDP. They appear at the number of small enterprises that decreased from 2010 to 2013 , figure 4 . Changes on the economy on 2014 as the growth, even limited, of GDP caused a growth of the number of enterprises that declined again after the capital control measures undertaken at the end of June 2015. The Greek government was forced to close Greek banks for three weeks, (from 29 of June 29 to 20 of July), and cash withdrawals were reduced to a total of 60 euros per day, in order to avoid an uncontrollable bank run and a complete collapse of the Greek banking system. Progressively the amount of withdrawals grew up. The complete abolition of capital controls was applied from September 2019. The growth of the GDP on 2017 was not followed by the growth of the total number of enterprises. The decline at the second period was influenced mainly by the sectors on construction, since this sector has experienced the largest decrease in its activity, followed by the manufacturing. On the contrary sectors such as accommodation, real estate, professional, scientific and technical activities presented a growth of the number of enterprises. The total number declined nevertheless. 


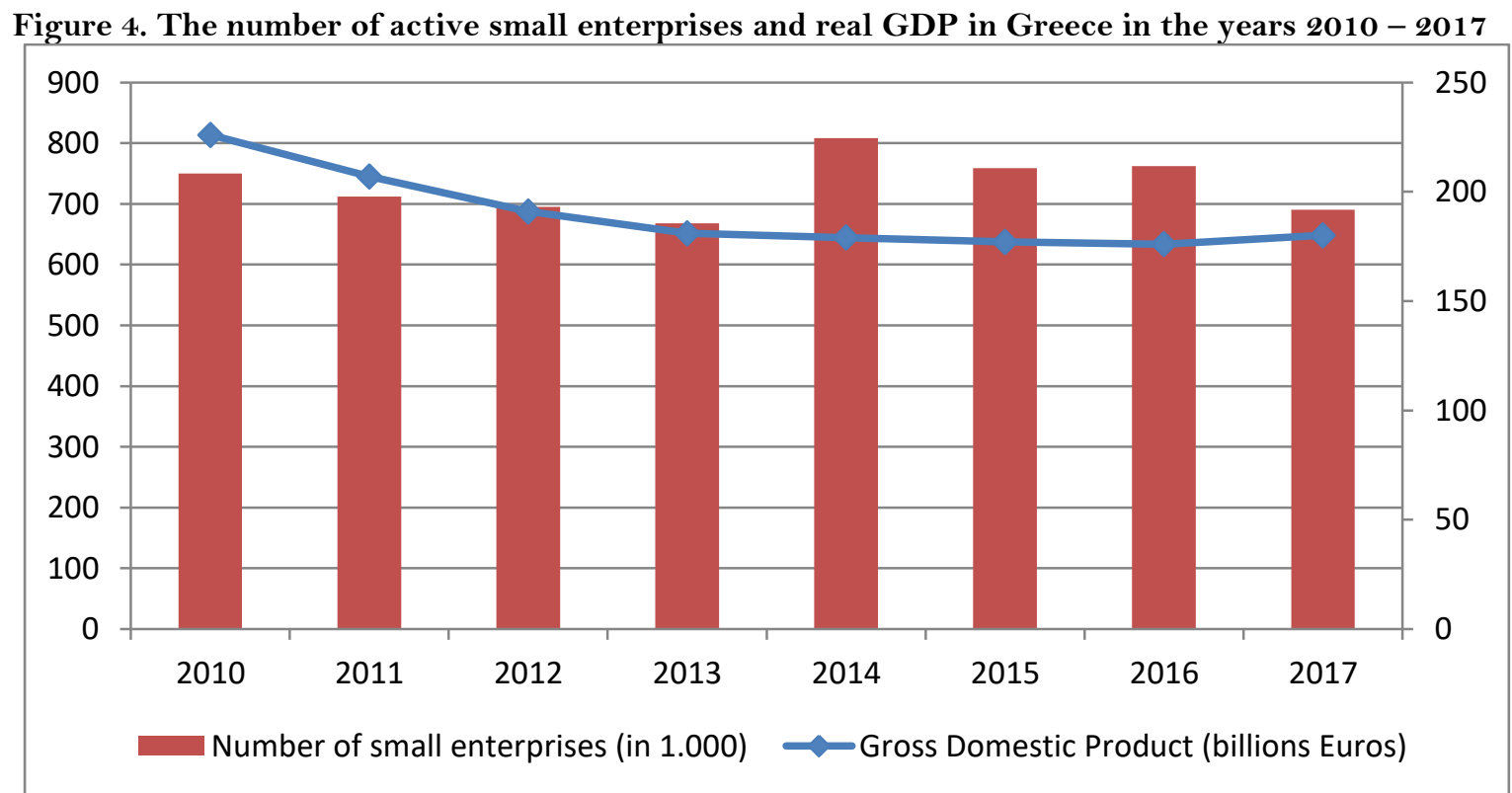

Eurostat, 2019, author's calculations

The number of employees seems to suffer more from the economic crisis and in particular the policy decisions. The years that followed the adjustment program caused the decline on the number of employees, figure 5. On 2014, the first year GDP had a limited growth, a strong growth of the employment is observed; the next year, the imposition of capital controls provoked a very serious decline of the number of employees in the small enterprises. The companies seem to suffer mostly from the capital controls.

Figure 5. The number of employed in small enterprises and real GDP in Greece in the years $2010-2017$

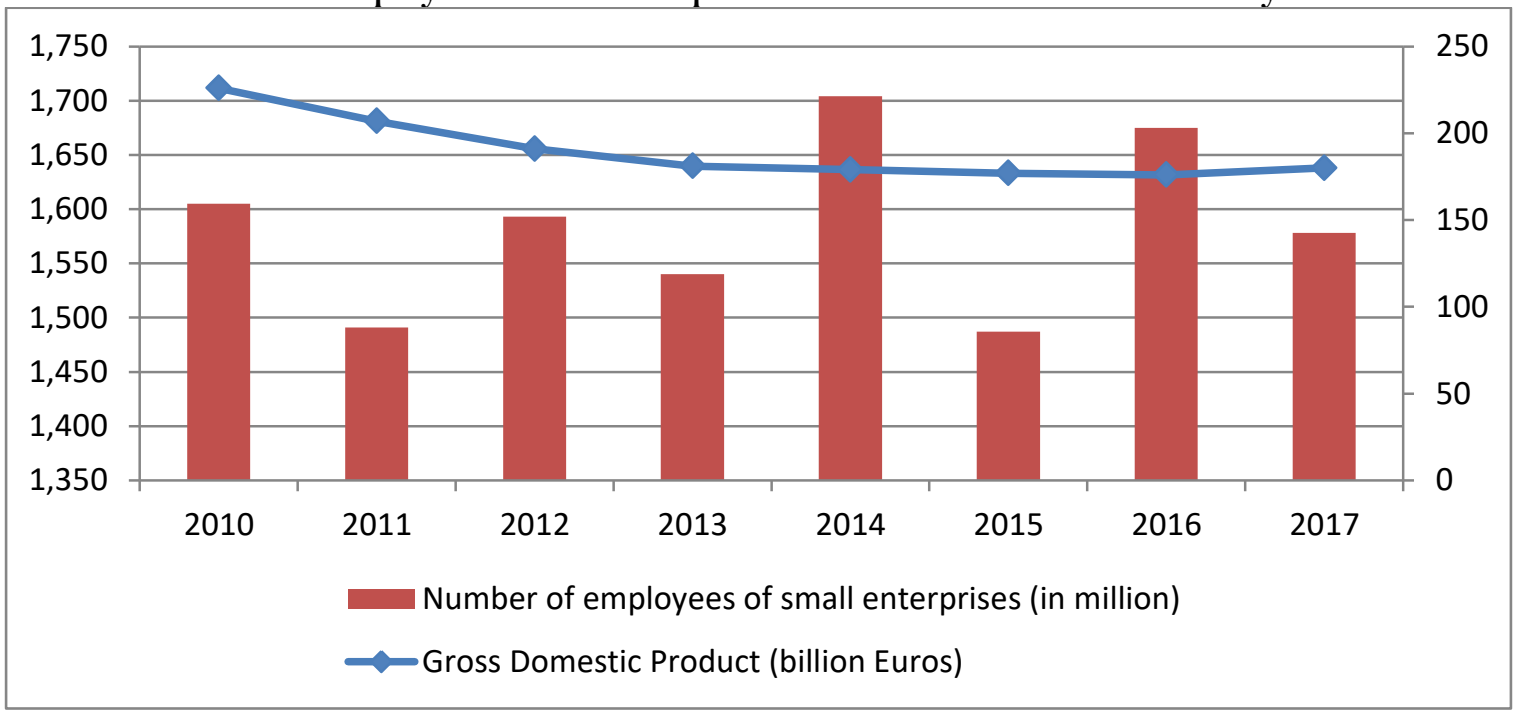

Source: As figure 4

This phenomenon may indicate also that employment is the parameter the most influenced from any decision on economic and credit policy. One has to notice, however, that part of the unemployment is replaced by the undeclared work.

Small enterprises lost significant part on the country's GDP, by considering the added value produced. Their part to country's GDP was almost 15\% on 2010, figure 6. Under the exception of 2012 and 2013 their part to GDP declined the examined period. Their share of the country's GDP was $12,4 \%$ on average the examined the period. The second half of the examined period this share was only $10,2 \%$. This evolution characterized particularly the sector of 
wholesales, the sector of construction, manufacturing and accommodation for the benefit of big companies, (having more than 250 employees).

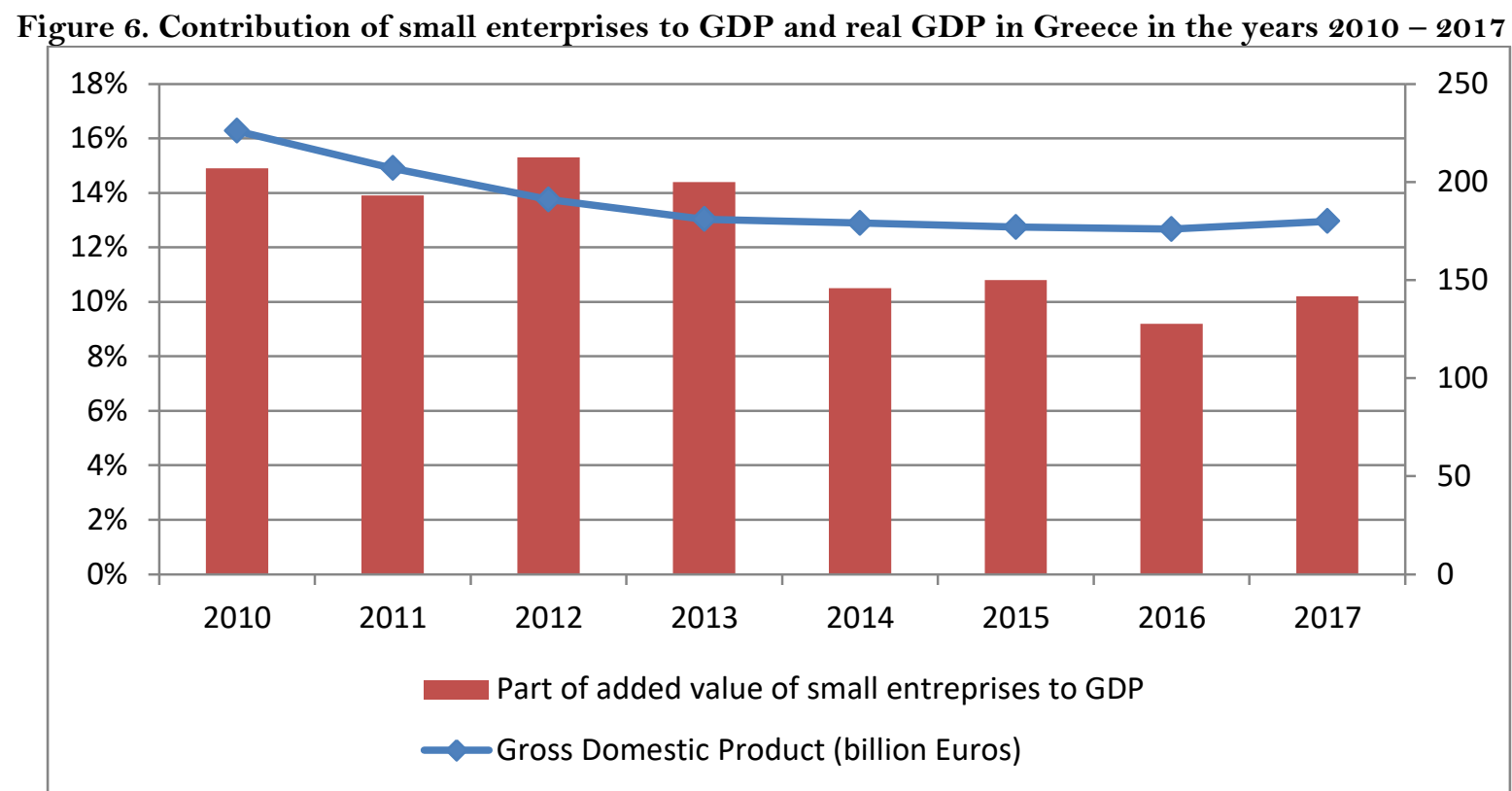

Source: As figure 4

\section{Conclusion}

Small enterprises are an important part of the economic structure in many countries both in Europe and in the world. Despite many publications on this subject, the authors have identified the research gap regarding the development of these companies. Therefore, they attempted to answer the following research questions:

a/ How the number of active small enterprises was changing this period?

The global economic crisis caused a slowdown in economic growth in Poland, which coincided with the decreased number of active small enterprises. In subsequent years, however, this number started to increase slowly again. It reached a maximum point in 2017 , approximately 2 million of small enterprises. In the Greek case, the financial crisis and in particular the austerity programs influenced the evolution of the number of small enterprises. A significant relation appears between the growth of GDP and the number of small enterprises. The strong decline of GDP especially the first sub-period resulted to the significant decline of the number of small enterprises; they passed from 750.000 on 2010 to 668.000 by the end of 2013 . The same sub-period the GDP lost almost $20 \%$. On the second half, the cessation of the large decline in GDP caused the increase in the number of small businesses that was placed on almost 755.000 in average the second period, 2014-2017.

b/ How the number of people employed in small enterprises was changing?

Despite the decrease in the number of employees in Polish small companies (about 4,5 million of employees) during the global economic crisis, the following years brought stable growth. As a result, there were about 4,8 million people at the end of the period under review. In the Greek case the number of employees has been influenced by the austerity programs and further from decisions on economic and credit policy; the consequences were much more serious compared to the other two parameters, especially on 2011 the year after the begin of the austerity program and 2015 , the year of capital controls; the loss of more than one hundred thousand and two hundred thousand jobs were recorded respectively these two years, even if it is a consequence, to some extent, of unregistered work

c/ How the contribution of small enterprises to GDP was changing?

The contribution of small companies in GDP reached the maximum point in Poland in 2013, almost 40\%. Since then, this share has changed only a little (38,5\%-39,0\%). However, taking into account economic growth at that time, its value continued to increase. Small enterprises loose a part on the GDP in the Greek case in favor of bigger companies especially on the second half of the examined period. Their part to GDP passed from 14,5\%, in average, the first half of the examined period, 2010-2013 to 10,25\% the second half. This evolution is the consequence of the economic environment but also because of difficulties of financing since these enterprises had more difficulties in accessing baking credit than big companies.

The paper contributes to the market failure theory in the area of macroeconomic business cycles. As the downswings because of crises influence on activity of enterprises, there is a need of appropriate government intervention. The analyzed examples suggest that higher level of monetary and credit policy in Poland seems to have a positive impact on the development of small enterprises in the analyzed space time. On the contrary, the austerity program in Greece that belongs to the Eurozone might negatively affect the small companies. 
It should be noted that the presented results are based on quantitative methods, while the economic development also covers qualitative issues. Nevertheless, the analysis of data suggests the existence of a relationship between the adopted measures of small enterprises development and the value of GDP. Therefore, it indicates the need for further research, using more advanced methods of analysis. It is also worth expanding the research using qualitative methods.

\section{Acknowledgement}

The present study has been presented at the $12^{\text {th }}$ International Conference "Economies of the Balkan and Eastern European Countries", EBEEC 2020, that has been online held in Opatija, Croatia from May $29^{\text {th }}$ to $31^{\text {th }} 2020$ (http://ebeec.ihu.gr).

\section{References}

Bank of Greece, 2016. Bulletin of Conjunctural Indicators, no 166, January-February 2016,

Bank of Greece, 2019. Bulletin of Conjunctural Indicators, no 189, November-December 2019,

Bank of Greece, 2019a. Statistics: Evolution of loans and non-performing loans,

Bednarczyk, M., 2004. Mate i średnie przedsiębiorstwa w Polsce a integracja europejska, Wydawnictwo AE w Krakowie, Kraków.

Borowiecki, R. and B. Sita-Tokarska, 2008. Problemy funkcjonowania i rozwoju małych i średnich przedsiębiorstw w Polsce, Difin, Warszawa.

Criscuolo, C., Gal, P, and P. Menon, 2014. "The Dynamics of Employment Growth - New Evidence from 18 Countries", CEP Discussion Paper No 1274.

Daszkiewicz N., 2007. Teorie internacjonalizacji MSP - ewolucja i perspektywy rozwoju, w: N. Daszkiewicz (red.), Małe i średnie przedsiębiorstwa. Szanse i zagrożenia rozwoju, CeDeWu, Warszawa.

Daszkiewicz, N., Wasilczuk J. and P. Dominiak, 2005. Małe i średnie przedsiębiorstwa wobec procesów integracji gospodarki światowej - teoria i metodologia badań, w: N. Daszkiewicz, J. Wasilczuk, P. Dominiak (red.), Małe $i$ średnie przedsiębiorstwa w obliczu internacjonalizacji i integracji gospodarek europejskich, Scientific Publishing Group, Gdańsk 2005.

Dominiak, P., 2010. Sektor MSP na Pomorzu w warunkach pogorszenia koniunktury. Raport z badania matych $i$ średnich przedsiębiorstw w ramach Pomorskiego Obserwatorium Gospodarczego III, Agencja Rozwoju Pomorza, Gdańsk.

Dominiak, P., 2005. Sektor MSP we wspótczesnej gospodarce, PWN, Warszawa.

Duda, J. and M. Woźniak, 2018. "Bank policies towards SME sector in Poland and selected countries worldwide", Managerial Economics, vol 19, no. 1.

European Commission, 2016. User guide to the SME definition, Ref. Ares (2016)956541, 24-2-2016

Eurostat, 2019. Annual enterprise statistics by size class for special aggregates of activities, Greece, https://appsso.eurostat.ec.europa.eu/nui/submitViewTableAction.do (accessed 4/2/2020)

Karafolas, S. 2013. "Public financial support to investments in rural areas: the case of the region of Thessaly in Greece”, International Journal of Economic Sciences and Applied Research, 6 (2), 81-101

Karafolas, S., 2018. "Effects of economic crisis: a regional examination based on touristic regions in Greece“, Vadyba/Journal of Management, 32 (1), 81-89.

Karafolas, S. and A. Kleanthous, 2019. “Crisis' consequences on recapitalization and exposure for Cypriot and Greek cooperative banks", CIRIEC España, Revista de Economía Pública, Social y Cooperativa, 96, 5-27. DOI: 10.7203/CIRIEC-E. 96.12974.

Matejun, M., 2015. Absorpcja wsparcia w zarzadzaniu rozwojem mikro, matych i średnich przedsiębiorstw - podejście strategiczne, Wydawnictwo Politechniki Łódzkiej, Łódź.

Muller, P., Caliandro, C., Peycheva, V., Gagliardi, D., Marzocchi, C., Ramlogan, R. and D.Cox, 2015. Editor, Hope, K. Annual Report on SMEs 2014-15, SMEs start hiring again, European Commission.

Muller, P., Devnani, S., Julius, J., Gagliardi, D. and C.Marzocchi, 2016, Editor: Hope, K., Annual Report on SMEs 2015-16, SMEs recovery continues, European Commission.

Muller, P., Julius, J., Herr, D., Koch, L., Peycheva, V. and S. McKiernan, 2017. Editor: Hope, K. Annual Report on European SMEs 2016-2017, Focus on self-employment SME Performance Review, European Commission.

Muller, P., Robin, N., Jessie, W, Schroder, J., Braun, H., Becker, L.S., Farrenkopf, J., Ruiz, F.A., Caboz, S., Ivanova, M., Lange, A., Lonkeu, O.K., Mühlschlegel, T.S., Pedersen, B., Privitera, M., Bormans, J., Bogen E. and T. Cooney, T., 2019. Editor: Hope, K. Annual Report on European SMEs 2018-2019, Research and Development and Innovation by SMEs, European Commission 
Nowa definicja MŚP. Poradnik dla użytkowników i wzór oświadczenia, 2006. Komisja Europejska.

Peszko, A., and J. Duda, 2004. Perspektywy konkurencyjności matych i średnich przedsiębiorstw matopolskich w procesie integracji europejskiej(w) Z. Olesiński, A. Szplit (red), Przedsiębiorstwo i region w zjednoczonej Europie, KNOiZ PAN; AŚ im. Jana Kochanowskiego w Kielcach, Kielce.

Piasecki, B., 1998. Ekonomika $i$ zarzadzanie mała firma, Wydawnictwo Naukowe PWN, Warszawa.

Piasecki, B., 2002. Przedsiębiorczość i rozwój matych i średnich przedsiębiorstw w XXI wieku, Wydawnictwo Uniwersyteckie, Łódź.

Raport o stanie sektora matych i średnich przedsiębiorstw w Polsce w latach 2009-2010, 2010-2011, 2011-2012, 2013-2014, 2016, 2017, 2018, PARP, Warszawa.

Union of Hellenic Chambers of Commerce and the Task Force for Greece, 2014. The development of SMEs in Greece, Policy Document.

Wach, K., 2008. Regionalne otoczenie matych i średnich przedsiębiorstw, Wyd. UEK, Kraków.

Wilmańska, A., 2010. Raport o stanie sektora matych i średnich przedsiębiorstw w Polsce w latach 2008-2009, Polska Agencja Rozwoju Przedsiębiorczości, Warszawa.

Woźniak, M., 2012. System wspierania matych i średnich przedsiębiorstw w Polsce, Wydawnictwa AGH, Kraków.

This is an Open Access article distributed under the terms of the Creative Commons Attribution Licence

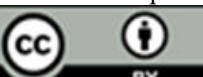

